\title{
H1-6 wt Allele
}

National Cancer Institute

\section{Source}

National Cancer Institute. H1-6 wt Allele. NCI Thesaurus. Code C162865.

Human H1-6 wild-type allele is located in the vicinity of $6 \mathrm{p} 22.2$ and is approximately $1 \mathrm{~kb}$ in length. This allele, which encodes histone $\mathrm{H} 1 \mathrm{t}$ protein is involved in chromatin architecture. 